\title{
Appraising the Implementation of the
}

\section{Accountancy, Business and Management (ABM) Strand of the Senior high School Curriculum in the Division of Science City of Munoz, Nueva Ecija, Philippines}

Maria Eloisa Mingala-Pagay, Jomel Villamante Mangawang, Felipe E. Balaria

Nueva Ecija University of Science and Technology, Graduate School-Business Administration, Cabanatuan City, Philippines mariaeloisapagay1981@yahoo.com,jv mangawang@yahoo.com.ph,pbalaria@yahoo.com

Abstract - This research aimed to conduct a formative assessment in the implementation of Accountancy, Business and Management (ABM) Strand in the Division of Science City of Muñoz for years 2016 and 2017. The study assessed three main areas or variables, namely: instructional input, conduct of instruction and outcomes of instruction. The study revealed a tremendous increase of over one and onehalf times its number compared to the previous year (2016) enrolment in ABM Strand which also accounted to learners' own preference and decision to enrol along this track was documented. It was also observed that the most basic instructional inputs such as classrooms, television, LCD projector, computer, and printer were deficient. Textbooks still served as the daily instructional material followed by hand outs and modules. It further revealed that teaching methodologies and strategies employed by the ABM teachers were varied as to the extent of use. Results further revealed that much of the instructional time was devoted to lecture method. The teacher-student and student to student interactions were not evidently seen in the study. In terms of assessment, Paper and Pen test was used as mode of assessment in order to measure and evaluate the learners' learning outcomes. On the contrary, in terms of output of instruction, learners still obtained outstanding and very satisfactory grades. Given the qualifications and vertical specialization ofteachers and the limitations cited, studentlearners managed to acquire quality education.

Keywords-K to 12Program, Accountancy, Business and Management Strand, Implementation.

\section{INTRODUCTION}

The landscape of the basic education in the Philippines was changed in 2012; from 10 years to 12 years termed as
Kindergarten to 12 (K-12) Program. The Philippine government finally enacted into law Republic Act 10533, otherwise known as the Enhanced Basic Education Act of 2013 on May 15, 2013(Caballero and Cabahug, 2015). Furthermore, there is a clear model of program tracks, namely: Academic, Technical and Vocational (Tech-Voc), Sports, and Arts and Design with at least 10 strands (Sarmiento and Orale, 2016) wherein Accountancy, Business and Management (ABM) is one.

More so, Department of Education (DepEd) argues that K12 program will be the solution to yearly basic education woes and the deteriorating quality of education(Philippine Online Chronicles, 2011).The additional two years in Senior High School (SHS) started on School Year (SY) 2016 (Sarmiento and Orale, 2016).

Meanwhile, only four schools offer SHS in Schools Division of Science City of Munoz, Of these, only the Munoz National High School- (MNHS)offer Academic Tracks namely: Humanities and Social Sciences (HUMSS), Accountancy, Business and Management (ABM), and Science and Technology, Engineering and Mathematics (STEM); and b) Technology-Vocational and Livelihood (TVL)Track consists of Home Economics (HE), Shielded Metal Arc Welding (SMAW), Information, Communication and Technology (ICT) respectively.

Preliminary survey further revealed that other schools do not offer the ABM Strand due to following reasons, namely: a) need-based criteria of the community (Larosa, 2018);b) lack or no available resources and facilities related to business;c) small number of Grade 11 enrolees who chose ABM during pre-registration activity (Alvarez, 2018); and d) few potential industry partners for immersion activity 
including the travelling expenses incurred (Romagosa, 2018).

Since MNHS is the only school in the Division offering ABM Strand, a formative assessment on the implementation of this strand is imperative to know the effectiveness of its implementation which may help them improve the system. Specifically, the study analysed three main components or variables such as a) instructional inputs in terms of students, teachers and facilities and equipment; b)conduct of instruction based on instructional materials used, methods and s strategies of teaching employed, and assessment of student's learning adopted; and c) outcomes of ABM instruction.

\section{METHODOLOGY}

Thestudy framework used the General System's Theory of Ludwig von Bertalanfy(1968). In his theory, he posits that an organization operates as a system based of interdependent parts operating as a whole for some purpose. Bertalanfy claimed that the total parts contained in a system and the relations between them are known and defined clearly, the behaviour of the system may be derived from the behaviour of its parts" (Guberman, no date). Put differently, "the whole is the sum of its parts", and this is the synergy component of the system (Orpilla, 2014). . Figure 1 shows the study paradigm

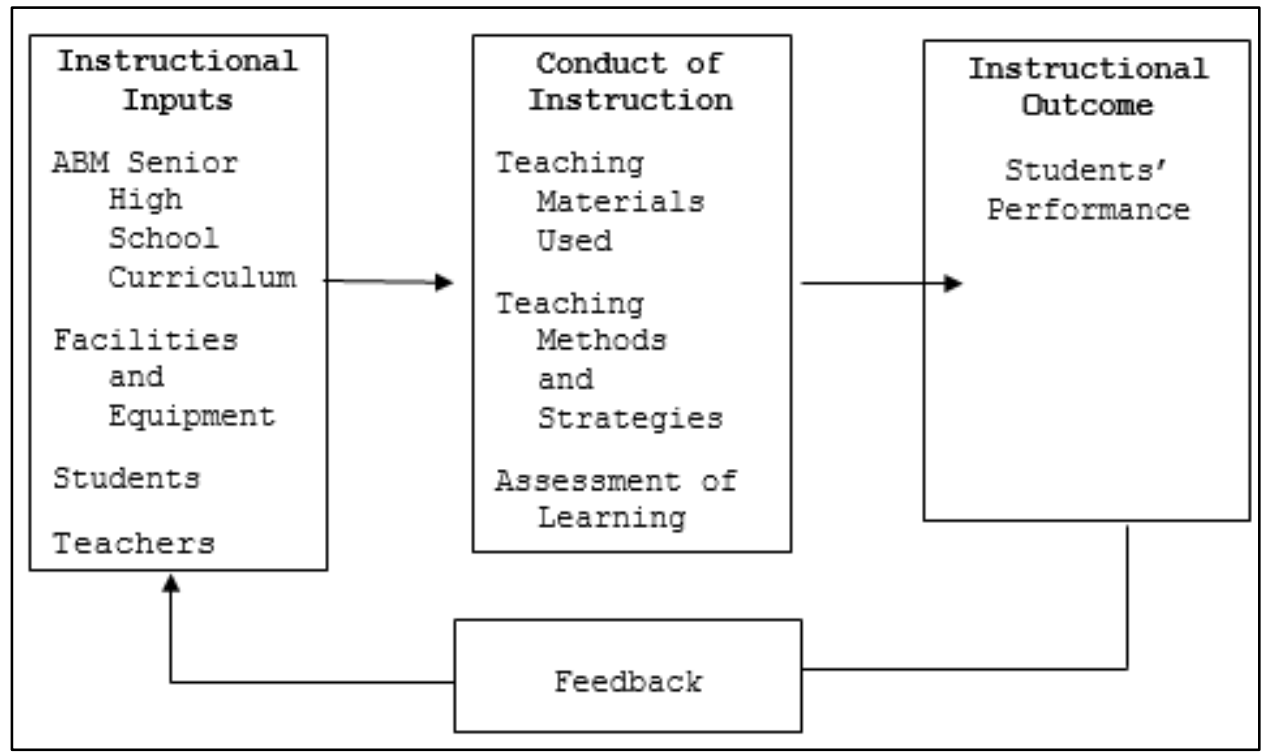

Fig.1: The Research Paradigm

The input box includes the SHS ABM Curriculum, Students, Teachers, and Facilities and Equipment. The process box contains variables on conduct of instruction measured in terms of instructional materials used, teaching methods and strategies employed, and assessment of students' learning. The output box contains the outcome of instruction measured in terms of students' performance. The feedback loop provides information as to how the system's flow and relationship of the variables
The descriptive research design was employed in the study. In particular, the instructional inputs, conduct of instruction, and instructional outputs were specifically discussed.

The study was conducted at Munoz National High School at Science City of Muñoz, Nueva Ecija during the first semester of School Year 2018-2019.

As to study locale, Science City of Muñoz is one of the five (5) cities in Nueva Ecija. It is traversed by the Maharlika National Highway going to Cagayan Valley Region and a secondary national road going to Pangasinan. 


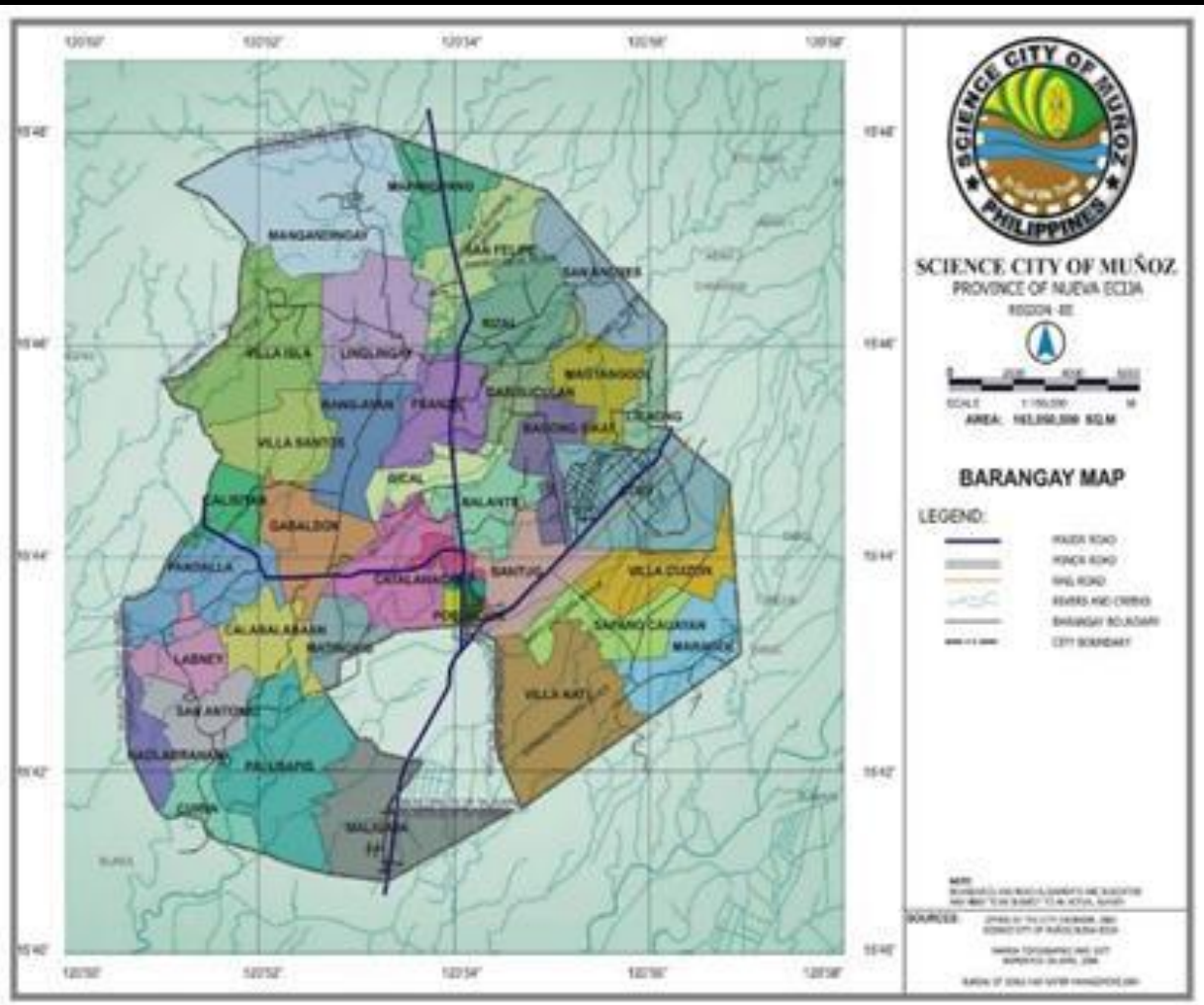

It is situated 147 kilometers North of Manila or 30 kilometers away from Cabanatuan City. It is bounded by six municipalities and one city, such as Municipality of Lupao on the North, Municipality of Talugtug on the Northwest, Municipalities of Santo Domingo and Talavera on the Southwest, Municipality of Guimba on the West, and the Municipalities of Llanera and San Jose on the East(Science City of Muñoz Handbook).

The research employed the purposive technique of nonrandom sampling. The study purposely selected the MNHS - Main Campus, among the four public schools implementing the SHS Program in the Division of Science City of Munoz, Nueva Ecija. Only MNHS-Main School in the Divisionoffers the ABM Strand.Out of 312 Grades 11 and 12 students enrolled in the aforementioned, 176 served as study respondents. Ninety-three (93) were Grade 11 and 83 were in Grade 12, respectively. The sample size was computed using the Raosoft sample size calculator software. In the same school, all ABM teachers were likewise served as respondents of the study.

Two sets of questionnaires for the SH students and for ABM teachers were utilized. The questionnaire for students included the reasons in choosing the ABM Strand, facilities and equipment used for instruction, how instruction was conducted based on methods and strategies used by their teachers. The questionnaire for teachers comprised items on their educational attainment, subjects taught, facilities and equipment, how instruction was conducted based on instructional materials used, teaching methods and strategies employed, assessment of students' learning, and the outcome of instruction. Problems encountered in teaching ABM subjects were also asked.

The instruments were checked by the adviser and the personnel of the Data and Statistical Analysis Center of Nueva Ecija University of Science and Technology (NEUST). To check the instruments clarity of content and direction, these were "tried out" or pre-tested in MNHS Annex Campus. After which, results of the said initial or practice test was considered in the final draft of the study instruments or questionnaires.

The researchers requested permission from the Office of the Schools Division Superintendent of the Division of Science City of Muñoz to conduct the study before the actual gathering of data was made. After the approval of request, coordination with the SHS Principal, ABM Subject Group Coordinator/Head, ABM teachers and selected 176 Grades 11 and 12 learners were made. Instruments were administered on the dates agreed upon. The researchers were present in the administration of the instruments. Retrieval of instruments followed after the administration. Observation on the facilities and equipment used for ABM instruction was made after the initial gathered data were organized and analysed.

In the aspect of data analysis technique, inputs to ABM instruction were discussed based on students, teachers, and facilities and equipment. As to students, the total enrolment 
in the ABM Strand during the S.Y. 2016 and 2017 was identified and compared and the reasons why students chose $\mathrm{ABM}$, and were ranked based on the frequency of the reason/s given. The teachers were described in terms on the subject/s taught and their educational attainment (Figure 1). The alignment of the subjects they are teaching and their educational attainment were described in terms of their alignment. In addition, the facilities and equipment were textually described as to availability. Meanwhile, the conduct of instruction was based on instructional materials used (Table 3), teaching methods and strategies employed (Tables 4, 5, 6), and assessment of students' learning adopted (Table 7). The teaching methods employed were enumerated per teacher, and the extent of use of these methods was described using the descriptors always, sometimes, and never.Outcome of ABM instructions was based on the grade point averages of all learnerrespondents in all ABM specialized subjects (Table 9).

\section{RESULTS AND DISCUSSION}

\subsection{Input of Instruction}

\subsubsection{Students}

Results of the study showed a large increase in enrolment in the ABM Strand within the schoolyear (2017) was documented. The increase in Year 2 (2017) enrolment surpassed the initial enrolment in Year 1 (2016). A percentage increase of 171.30 percent was obtained.Table 1 presents theenrolment data in the ABM Strand at MNHS in years 2016 and 2017.

Table.1: Two years Students' Enrolment Data in the ABM Strand

\begin{tabular}{|c|c|c|c|}
\hline Year & Number & $\begin{array}{c}\text { Enrolment } \\
\text { Increase }\end{array}$ & $\begin{array}{c}\text { Percentage } \\
\text { Increase }\end{array}$ \\
\hline 2016 & 115 & & \\
\hline 2017 & 312 & 197 & $171.30 \%$ \\
\hline
\end{tabular}

Seventy-two $(72 \%)$ percent of the students said that the choice of the ABM strand was their own preference and decision. Only 33 students for every 100 students said that they considered their interest in the field of ABM, and 31 per 100 students wanted to become entrepreneurs after finishing SHS if they would not be able to enrol in college. Only about 20 to 22 percent were influenced by their classmates and parents. Sixteen students have family business which they want to manage in the future. Very few students ( $7 \%$ only) considered their teachers' advice in choosing ABM. The given results imply that the reasons on the choice of the ABM track emanated from their own personal decision and interest. Table 2 represents the reasons of the students in choosing the ABM Strand.

Table.2: Students' Reasons for Taking ABM Strand

\begin{tabular}{|c|c|c|c|c|}
\hline $\begin{array}{l}\mathbf{N} \\
\mathbf{0}\end{array}$ & Particulars & $\begin{array}{c}\text { Frequen } \\
\text { cy }\end{array}$ & $\begin{array}{c}\text { Percent } \\
\text { age }\end{array}$ & $\begin{array}{c}\text { Ran } \\
\mathbf{k}\end{array}$ \\
\hline 1 & $\begin{array}{l}\text { Own Preference } \\
\text { Interested with } A B M\end{array}$ & 127 & 72 & 1 \\
\hline 2 & $\begin{array}{l}\text { Subjects } \\
\text { Become Future }\end{array}$ & 58 & 33 & 2 \\
\hline 3 & $\begin{array}{l}\text { Entrepreneur (after } \\
\text { SHS) } \\
\text { Influence by }\end{array}$ & 54 & 31 & 3 \\
\hline 4 & Classmates/Friends & 39 & 22 & 4 \\
\hline 5 & $\begin{array}{l}\text { Parents' Choice } \\
\text { Manage Family }\end{array}$ & 36 & 20 & 5 \\
\hline 6 & Business & 28 & 16 & 6 \\
\hline 7 & Teacher's Advice & 12 & 7 & 7 \\
\hline 8 & Other Reasons & 5 & 3 & 8 \\
\hline
\end{tabular}

\subsubsection{Teachers}

The highest educational attainment of the teachers is shown in Figure 2. Only four teachers are teaching the specialized subjects in the ABM track in Grades 11 and 12, namely: Entrepreneurship, Organization and Management, Busines s Marketing, Business Economics, Fundamentals of Accounting I and II, Business Mathematics, and Business Finance. Each teacher handled a minimum of 40 students and a maximu $\mathrm{m}$ of 55 .

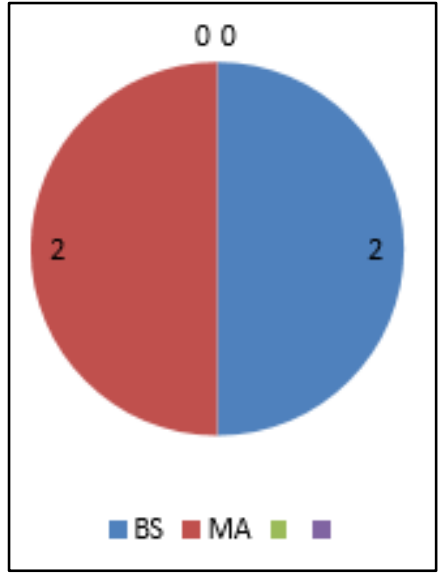

Fig.2: Educational Attainment of the Teachers

All four teachers hold bachelor's degree in Agribusiness Management and Business Management. Two of them likewise finished Master's degree in Agribusiness Management and Business Administration in state universities in the province. One of the teachers has earned 
doctorate units only in the same field. Their educational attainment and the subjects that they are teaching are vertically aligned; hence they sufficiently possess the content knowledge in teaching these subjects

\subsubsection{Facilities and Equipment}

All four teachers maintainedtheir classrooms, the areas as of which were just enough for the class size of 40 to 55 students. The classrooms are ventilated with ceiling and wall fans. Two teachers said the ventilation were enough while two teachers said that the electric fans were few. The lighting condition of the classrooms was just right. All teachers did not use laboratory room in their classes.

The following were the provisions to be made available in the classrooms namely: students' chairs, teacher's table and chair, blackboard, television printers, and supplies like chalk. Not all classrooms are furnished with television, LCD projector, computer, and printer.

With such limitations in the provision of equipment, conduct of instruction is affected. Some of the teachers opined that these lack of equipment in the clas sroom should be provided at the earliest possible time in order to offer better or the quality of instructionrequired of an $\mathrm{ABM}$ graduate.

\subsection{Conduct of Instruction in $\mathrm{ABM}$}

The classes in ABM were conducted four times a week with one hour time allotment.

\subsubsection{Instructional Materials Used}

The instructional materials used in the ABM classes at MNHS are shown in Table 3. The common instructional material used in every day ABM classes was a textbook. Hand outs were sometimes used by three teachers. Three of them also used modules. Although the four teachers used power point slides in teaching, this instructional material was not used every day by the four teachers. With the limited number of the LCD projector, its use was made by schedule. Since the LCD was not available every day in all $\mathrm{ABM}$ classes, the ABM teachers compensated the shortage by using pictures and lectures posted on cartolina. Only one teacher had lecture printed in tarpaulin.

Table.3: Instructional Materials Used in ABM Classes

\begin{tabular}{|l|c|c|c|}
\multicolumn{1}{c|}{$\begin{array}{c}\text { Instructional } \\
\text { Material }\end{array}$} & Class A & Class B & Class C \\
\hline Textbooks & $/$ & $/$ & $/$ \\
\hline Hand outs & $/$ & $/$ & $/$ \\
\hline Modules & & $/$ & $/$ \\
\hline Power point slides & $/$ & $/$ & $/$ \\
\hline Visual materials like pictures & & $/$ & $/$ \\
\hline Lecture posted in cartolina & $/$ & $/$ \\
\hline Lecture in tarpaulin & & $/$ & \\
\hline
\end{tabular}

It was observed that the textbook was the main source of information of the students and teachers. The use of instructional materials generated from e-technology was minimal.

3.2.1 Methods and Strategies Employed in Teaching

The teaching methodologies and strategies employed by the ABM teachers vary as to the extent of use.

\section{Classes $\mathrm{A}$ and $\mathrm{C}$}

Teachers A and Cused five teaching methods/strategies in their ABM classes. These teaching methodologies and their extent of use are shown in Table 4.Note that they never used the lecture method with novisual aid posted on the board. Whenever the two teachers used the lecture method, the lecture is accompanied by power point presentation.

Table.4: Teachers A and C Teaching methodologies/strategies used and the extent of use

\begin{tabular}{|l|c|c|}
\multicolumn{1}{|c|}{ Method/Strategy } & \multicolumn{2}{c|}{ Extent of Use } \\
\cline { 2 - 3 } & \multicolumn{1}{|c|}{ Always } & Sometimes \\
\hline Lecture with no visual aid & & \\
\hline Lecture with visual aid posted on the board & & \\
\hline Lecture with power point presentation & $/$ & \\
\hline Group discussion after the teacher's lecture & $/$ & \\
\hline Role Playing & & \\
\hline Reporting & & $/$ \\
\hline Instructional Games & & $/$ \\
\hline
\end{tabular}


Under the always category, the lecture was followed by group discussion. Role playing, reporting, and instructional games were also sometimes used.

\section{Class B}

Table 5 shows the data on the teaching methods/strategies and extent of use employed by Teacher B.According to Teacher B, never did she use instructional games in her ABM class. She claimed that although the students enjoyed playing games, this method usually consumes so much instructional time. When the LCD projector was not available, she sometimes delivered her lecture with no visual aid and when there were pictures available, she posted these on the board while delivering the lecture. When it was her turn to use the LCD, she always delivered her lecture thru the power point presentation. After lecture, student group discussion or teacher-students discussions always followed.Role playing and reporting were sometimes used in class

Table.5: Teaching methods/strategies and extent of use employed by Teacher B

\begin{tabular}{|l|c|c|c|}
\hline \multicolumn{1}{|c|}{ Method/Strategy } & \multicolumn{2}{c|}{ Extent of Use } \\
\cline { 2 - 4 } & Always & Sometimes & Never \\
\hline Lecture with no visual aid & & $/$ & \\
\hline Lecture with visual aid posted on the board & $/$ & & \\
\hline Lecture with power point presentation & $/$ & & \\
\hline Group discussion after the teacher's lecture & $/$ & $/$ & \\
\hline Role Playing & & $/$ & $/$ \\
\hline Reporting & & & \\
\hline Instructional Game & & & \\
\hline
\end{tabular}

\section{Class D}

Table 6 presents the data on the teaching methods/strategies employed by Teacher D in her ABM classes and the extent of using these.

Table.6: Teaching Methods/Strategies Used by Teacher D and the Extent of Using Them

\begin{tabular}{|l|c|c|c|}
\hline \multirow{2}{*}{ Method/Strategy } & \multicolumn{2}{|c|}{ Extent of Use } \\
\cline { 2 - 4 } & Always & Sometimes & Never \\
\hline Lecture with no visual aid & & $/$ & \\
\hline Lecture with visual aid posted on the board & & $/$ & \\
\hline Lecture with power point presentation & & $/$ & \\
\hline Group discussion after the teacher's lecture & $/$ & $/$ & \\
\hline Role Playing & & $/$ & \\
\hline Reporting & & $/$ & \\
\hline Instructional Game & & $/$ & $/$ \\
\hline
\end{tabular}

Six teaching methods/strategies were sometimes employed by Teacher $\mathrm{D}$ in her ABM classes. These were lecture method with no visual aid, lecture with pictures posted on the board, and lecture using power point presentation. Never did the teacher use the lecture method without visual aids. Group discussion always followed the teacher's lecture.

It can be observed from the foregoing results that lecture was the primary teaching method used by the ABM teachers. The use of e-technology through power point presentation was not fully maximized due to the limited number of LCD units that the school has. The other teaching methods were sometimes used because of the longer instructional time that these teaching methods may be applied as claimed by the teachers.
The learner's engagement to learning tasks was not so evident. Much of the instructional time was devoted to the teacher's lecture. Because of these limitations, the teacherstudent, and student to student interactions were not evidently seen.

The instructional climate in the classroom is the result of the instructional equipment use, which also eventually influences the teaching method and strategies employed by the teacher. The learning engagement of the students is also affected in this kind of learning environment.

A well-balance blend of the instructional materials used and the methods/strategies employed by the teachers, and the learning engagement of the learners is necessary to produce the maximu $\mathrm{m}$ outcomes of instruction.

\subsubsection{Assessment of Students' Learning Adopted}


The ABM teachers and some of the students interviewed at random confirmed that the "Paper and Pen test" was the primary mode of assessment used to as sess and evaluate the students' learning outcomes. The test constructed by the teachers had different formats. In the said tests, the students were usually asked to select or supply the answer to the given test items.

The ABM teachers Performance-based and Portfolio assessment were seldom used. This finding is triangulated by the teaching method/strategies employed by the ABM teachers.

The Grading System in the Academic Track of Grades 11 and 12 in Senior High School, where ABM is clustered is shown in Table 7.

Table.7: Grading System Components and their Weight in SH-ABM track

\begin{tabular}{|l|c|}
\hline \multicolumn{1}{|c|}{ Grading System Components* } & $\begin{array}{c}\text { Weight of Component in } \\
\text { Academic Track }\end{array}$ \\
\hline Written Work & $35 \%$ \\
\hline Performance Tasks & $40 \%$ \\
\hline Quarterly Assessment & $25 \%$ \\
\hline
\end{tabular}

*Source: Department Order No. 8, s 2015

Table 8 below shows the descriptors, grading scale in Senior High School

Table.8: Descriptors of the Grading Scale

\begin{tabular}{|l|c|c|}
\hline \multicolumn{1}{|c|}{ Descriptor } & Scale & Remarks \\
\hline Outstanding (O) & $90-100$ & Passed \\
\hline Very Satisfactory(VS) & $85-89$ & Passed \\
\hline Satisfactory (S) & $80-84$ & Passed \\
\hline Fairly Satisfactory(FS) & $75-79$ & Passed \\
\hline Did Not Meet Expectation (DNE) & below 75 & Failed \\
\hline
\end{tabular}

*Source: Department Order No. 8, s 2015

Callingham (2010) pointed out however, that assessment is viewed as more than the data collection about learners. It likewise incorporates the process of drawing inferences from the data collected and acting on those judgments in effective ways.

\subsection{Outcomes of Instruction in ABM Subjects}

Table 9 presents the average grades obtained by the Grade 11 and 12 SH students in their ABM Subjects.

Table 9. Average grades obtained by Grade 11 and Grade 12 Students

\begin{tabular}{|l|c|c|c|c|}
\hline \multicolumn{1}{|c|}{ ABM Subjects } & Grade 11 & Description & Grade 12 & Description \\
\hline Organization and Management & 88 & V VS & & \\
\hline Business Mathematics & 88 & V VS & & \\
\hline Business Finance & & & 86 & VS \\
\hline Fundamentals of Accounting I & & & 90 & O \\
\hline Fundamentals of Accounting II & & & 89 & VS \\
\hline Entrepreneurship & & & 88 & VS \\
\hline Marketing & & & 89 & VS \\
\hline
\end{tabular}

The outcome of ABM instruction to the students who had taken the different subjects was impressive. Despite the limitations found on the inputs of instruction on facilities and equipment, the students got very satisfactory and outstanding grades in the different subjects.

\section{SUMMARY, CONCLUSIONS AND RECOMMENDATIONS}

As the central part of this descriptive research, the formative assessment on the implementation of ABM
Strand of the Senior High School Curriculum in the Division of Science City of Munoz. Three main variables were analysed in this study, namely: a) instructional inputs in terms of students, teachers and facilities and equipment; b) conduct of instruction based on instructional materials used, methods and strategies of teaching employed, and assessment of students' adopted learning; and c) outcomes of instruction in ABM.

Employing the purposive sampling of non-probability sampling, the study involved 176 respondents from 312 
MNHS-Main (SHS) total enrolees, which consisted of 93 Grade 11 learners and 83 Grade 12 leaners. Furthermore, 4 ABM teachers (total enumeration) were interviewed.

The study utilized two sets of questionnaires for the $\mathrm{SH}$ students and for ABM teachers.

\section{Summary of Findings and Conclusion}

Percentage increase of 171.30 in Year 2 (2017) enrolment surpassed the Year 1 (2016) of ABM Strand (Table 1) accounted to learners' own preference and decisions (Table 2). Learners' choice defined his/her future careers. Personal career choice considered the innate strengths that shaped the said reference.

Four ABM qualified SH teachers who taught ABM specialized subjects both in Grades 11 and 12, with 40-55 learners on the average, namely: Entrepreneurship, Organization and Management, Business Marketing, Business Economics, Fundamentals of Accounting I and II, Business Mathematics, and Business Finance. Teachers' educational attainment and the subjects taught were vertically aligned. Thus, they sufficiently possess the content knowledge in teaching the aforementioned ABM subjects (Figure 2).

As regard the facilities and equipment, it was documented that most basic instructional inputs such as classrooms, television, LCD projector, computer, and printer were deficient. However, teachers exhausted all the possible means still and offered the best quality of instruction to learners.

Textbooks, on one hand, still served as the daily instructional material followed by hand outs and modules.

In relation to the preliminary findings on limited facilities/equipment (LCD projectors in particular), teachers rarely used PowerPoint slides. Nonetheless, they compensated the said insufficiency by their creativity. They used pictures and lectures posted on Cartolina and sometimes in tarpaulin. Again, lack of materials or facility, did not inhibit the quality of instruction planned for a specific day.

Meanwhile, teaching methodologies and strategies employed by the ABM teachers varied as to the extent of use.

For example, Teachers $\mathrm{A}$ and $\mathrm{C}$ did not use lecture method with no visual aid posted on the board. If they adopted the method, PowerPoint slides strengthened the class discussions. Sometimes role playing, reporting, and instructional games were likewise utilized. On one hand, Teacher B did not opted to educational games because of time constraints or insufficiency. LCD projector was used in the delivery of lessons whenever it was available. In its absence, sometimes the teacher delivered the lectures with no visual aid and when there were pictures available, she posted these on the board. Similar to Teachers A and C, reporting and role playing were occasionally used as mediums of instruction. Finally, Teacher D sometimes employed 6 teaching methods/strategies ABM classes, namely: lecture method with no visual aid, lecture with pictures posted on the board, and lecture using power point presentation. Lecture method was not used without visual aids. Group discussion was frequently followed the teacher's lecture.

Preceding results show that much of the instructional time was devoted to lecture method. The teacher-student, and student to student interactions were not evidently seen in the study. To answer this, Mazur (2009) proposed a change of traditional lectures by giving time to students to consolidate their notes that can provide reflection to what has been written.

Generally, the effectiveness of teaching methods relied much on the nature of the students, the difficulty of the lesson, the accessibility and sufficiency of instructional materials, the teacher's specialization and the classroom climate (Katigbak, 2011).

Primarily, the "Paper and Pen test" was used as mode of assessment in order to measure and evaluate learning outcomes. The grading system used was based on the Department Order issued for that purpose.

In terms of output of instruction, considering the aforementioned number of ABM teaching force, learners still obtained outstanding and very satisfactory grades between 88-90 average ratings (Table 9). Given the qualifications and vertical specialization of teachers, even huge or large number of learners (outmost 55 learners in a classroom) received the quality or scholarly education today's generation of student-learners deserved.

\section{Recommendations}

To further strengthen the implementation of ABM Strand for the Senior High School Curriculum in the Division of Science City of Munoz, it is recommended that the management provides the necessary facilities and equipment that would be of great help for both teachers and students in the conduct and inputs of instructions. Moreover, it is imperative to add classrooms and workshops due to escalating number of enrolees

Requisite also is to increase the manpower requirements who will handle / teach ABM subjects based on the required qualification standards.

It is recommended to conduct a tracer study of the graduates of ABM graduates as to their employment.

Other studies might consider widening the scope of the study to include other division/s which will then give 
comparison as to strategies employed in the implementation of the ABM Strand or include other tracks of the Senior High School Program.

\section{REFERENCES}

\section{Journals/Serials/Periodicals}

[1] Cabahug, R. \& Caballero, F. R. (2015). The K to 12 Senior High School Technical-Vocational Livelihood Track is Not at All Ready for Implementation. JPAIR Institutional Research Journal, 5(1). Retrieved from http://ejournals.ph/form/cite.php?id=12129

[2] Mazur, E. (2009). Farewell, Lecture? , Science 2, 323(5910), 50-51.

[3] Sarmiento D.H. and Orale R.L (2016).Senior High School Curriculum in the in the Philippines, USA, and Japan.Journal of Academic Research 01:3(2016), pp. $12-23$

\section{Websites}

[4] Felipe, A. and Porio, C. (2011) "The DepEd's Arguments on the Implementation of $\mathrm{K}$ to 12 ", Philippine Online Chronicles

[5] Hughes, G. (2009). "Students' Perceptions of Teaching Styles in Mathematics Learning Environments", Mathematics Teaching-Research Journal On-Line, Bronx Colleges of the City University of New York.www.hostos.cuny.edu/departments/math/mtrj 1

Organizational Manuscripts

[6] Callingham, D. (2010). "Preparing Teachers to Teach Mathematics with Technology", Oregon State University, Association for Mathematics Teacher Educators.

\section{Laws/Ordinances/ Memorandum}

[7] Republic Act 10533, Press Release, May 3, 2013.

[8] DepEd Order No.8, Series of 2015

\section{Unpublished Materials}

[9] Katigbak, E. (2011) Extent of Utilization of Teaching Methodologies in Mathematics Instruction in the Division of Lipa City: Its Implications to Instruction, Master's Thesis, Tanauan Institute School of Graduate Studies, Tanauan City.

[10] Orpilla, M. (2014) Administration of Special Education Fund in the Science City of Munoz, Nueva Ecija. Dissertation, Institute of Graduate Studies, Central Luzon State University, Science City of Munoz, Nueva Ecija

\section{Interviews}

[11] Alvarez E., personal communication, August 10, 2018

[12] Larosa J., personal communication, August 10, 2018
[13] Romagosa E.R, personal communication, August 10, 2018 